\title{
Genetic Variability Analysis for Yield and Nutritional Traits in Foxtail Millet [Setaria italica (L.) Beauv]
}

\author{
G.K. Pavan Kumar ${ }^{*}$, A.V.S. Durga Prasad, \\ C.V. Chandra Mohan Reddy ${ }^{2}$ and K.N. Sreenivasulu ${ }^{3}$ \\ ${ }^{1}$ Department of Genetics and Plant Breeding, ${ }^{3}$ Department of Statistics and \\ Computer Applications, Agricultural College, Mahanandi, A.P, India \\ ${ }^{2}$ RARS, Nandyal, A.P, India \\ *Corresponding author
}

\begin{tabular}{|l|}
\hline Ke y w or d s \\
Foxtail millet, \\
Genetic variability, \\
Heritability, \\
Genetic advance \\
\hline Article Info \\
\hline $\begin{array}{l}\text { Accepted: } \\
\text { 17 May } 2019 \\
\text { Available Online: } \\
\text { 10 June } 2019\end{array}$ \\
\hline
\end{tabular}

A B S T R A C T

An investigation was conducted to assess the magnitude of genetic variability, heritability (broad sense) and genetic advance as per cent of mean in 100 foxtail millet genetic resources for 18 metric traits. The analysis of variance (ANOVA) revealed highly significant differences among the genetic resources for all the metric traits studied. Phenotypic coefficient of variation (PCV) was greater than genotypic coefficient of variation $(\mathrm{GCV})$ for all the characters studied indicating that these characters were highly influenced by the environmental effects. Estimates of PCV and GCV values (>20\%) were high for copper, iron, magnesium, zinc, grain yield/ plant and number of productive tillers/plant implying wide spectrum of variation among the test genotypes studied. High heritability $(>60 \%)$ coupled with high genetic advance as per cent of mean registered by panicle length, number of productive tillers /plant, carbohydrate, calcium, magnesium, iron, zinc, copper, manganese and grain yield/ plant indicated that these traits were predominantely under additive gene action and their improvement is possible through simple selection strategies.

\section{Introduction}

Foxtail millet [Setaria italica (L.) Beauv], a climate resilient small millet is chiefly grown in arid and semi-arid regions of India. Currently, this crop is fast re-expanding in the context of climate changing scenario and food security concerns across India. It is primarily cultivated in the states of Andhra Pradesh, Karnataka, Maharashtra, Tamil Nadu,
Rajasthan, Madhya Pradesh, Uttar Pradesh and North Eastern states. In Andhra Pradesh, this small millet grown on an area of $51 \mathrm{k} \mathrm{ha}^{-}$ 1 , accounted for an average productivity of $945 \mathrm{~kg} \mathrm{ha}^{-1}$ (Annual Report, 2016-17). The grains of this millet are enriched with quality protein (leucine and methionine), $\beta$ carotene, minerals $(\mathrm{Ca}, \mathrm{Fe}, \mathrm{K}, \mathrm{Mg}$ and $\mathrm{Zn}$ ), antioxidants, dietary fibre, phytochemicals, vitamins $\left(\mathrm{B}_{1}, \mathrm{~B}_{2}\right.$ and $\left.\mathrm{B}_{3}\right)$ and possess low 
glycemic index, a requisite for healthy human diet (Murugan and Nirmalakumari, 2006). Despite its nutraceutical ability and economic significance, this small millet received little research attention for enhanced production and is still tagged as a neglected and underutilized crop. Therefore, special impetus for genetic improvement of foxtail millet is needed on account of its amenability to climate resilient agriculture and heavy market demand from health conscious consumers.

For the inception of any crop improvement programme, prevalence of wide spectrum of genetic variability in the population is a requisite in selection of desired genotype(s) (Reddy et al., 2013). Presence of high genetic variability offers much scope for crop improvement programme (Poehlman, 1987). Yield being a complex polygenic character, is influenced by its own attributes and environment. The phenotypic expression of a character is resultant of the interactions between genotype and environment. Hence, the total variation needs to be partitioned into variance due to genotype (heritable) and variance due to environment (non heritable) for assessing the true breeding behaviour of the genotype. Genetic variability estimated by various genetic parameters viz., genotypic coefficient of variation (GCV), phenotypic coefficient of variation (PCV), heritability and genetic advance.

Besides genetic variability, knowledge on heritability and genetic advance measures the relative degree to which a character is transmitted to progeny, thereby assists the breeder to formulate a suitable selection breeding strategy inorder to achieve the desired objective. Thus, estimation of genetic variability in conjunction with heritability and genetic advance gives an idea of the possible improvement of the character through selection. Hence an attempt was undertaken to estimate the magnitude of variation and assess the genetic parameters inorder to deploy a suitable breeding strategy for foxtail millet improvement programme.

\section{Materials and Methods}

Field studies at Regional Agricultural Research Station, Nandyal, Andhra Pradesh utilizing hundred foxtail millet genetic resources, drawn from 1037 foxtail millet germplasm collections of the institute were laid in a Augmented randomized complete block design (ARCBD) during Kharif, 2018 in order to study the genetic parameters viz., variability, heritability and genetic advance as per cent of mean. The experiment was carried out at an altitude of $211.3 \mathrm{~m}$ above mean sea level, latitude of $18.29^{\circ} \mathrm{N}$ and longitude of $78.29^{\circ} \mathrm{E}$ at RARS, Nandyal, A.P. The net plot size was $40 \times 3 \mathrm{~m}^{2}$ with a recommended spacing of $22.5 \mathrm{~cm} \times 10 \mathrm{~cm}$. The data was collected on five randomly selected plants per genetic resource for 18 metric traits viz., SCMR at 30 DAS, SCMR at 45 DAS, days to $50 \%$ flowering, plant height, panicle length, number of productive tillers /plant, days to maturity, number of grains / ear head, 1000 grain weight, protein, carbohydrate, calcium, magnesium, iron, zinc, copper, manganese and grain yield/ plant.

The various genetic parameters viz., phenotypic coefficient of variance (PCV) and genotypic coefficient of variance (GCV), heritability (broad sense) and genetic advance as per cent of mean were computed as per the procedres outline by Burton and Devane (1952), Lush (1940) and Johnson et al., (1955), respectively. The data obtained was subjected to analysis using WINDOWSTAT 9.2 version software..

\section{Results and Discussion}

The analysis of variance (Table 1) for 18 metric characters revealed highly significant differences among the foxtail millet genetic 
resources for all the characters indicating existence of ample genetic variability in the genetic resources utilized for study. The estimates of PCV was higher than GCV for all the traits observed (Table 2 \& Fig. 1) implying that the characters were less influenced by the environment. The characters copper (46.57 and 46.47), iron (46.42 and 46.33), magnesium (33.01 and 32.93), zinc (32.92 and 32.91), grain yield/ plant (29.62 and 29.05) and number of productive tillers /plant (24.85 and 24.75) registered higher PCV and GCV (>20\%) values respectively indicating that these characters contributed more to the total variability. Similar results were reported by Mahanthesha et al. (2017), Shingane et al., (2017) and Amarnath et al., (2018) for number of productive tillers / plant.

Fig.1 Genotypic and Phenotypic coefficient of variation for the characters studied

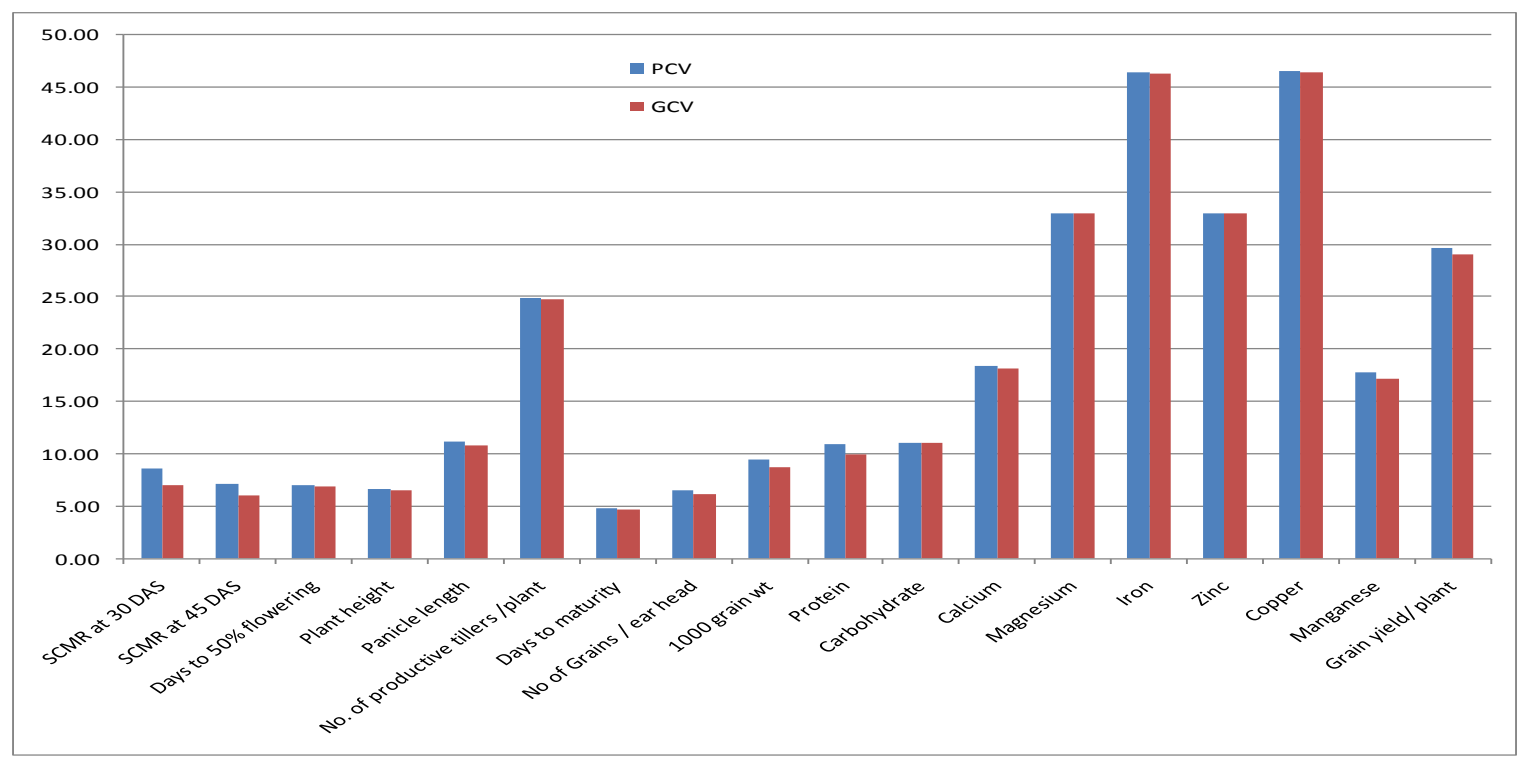

Fig.2 Pattern of heritability and genetic advance as per cent of mean for the analysed traits

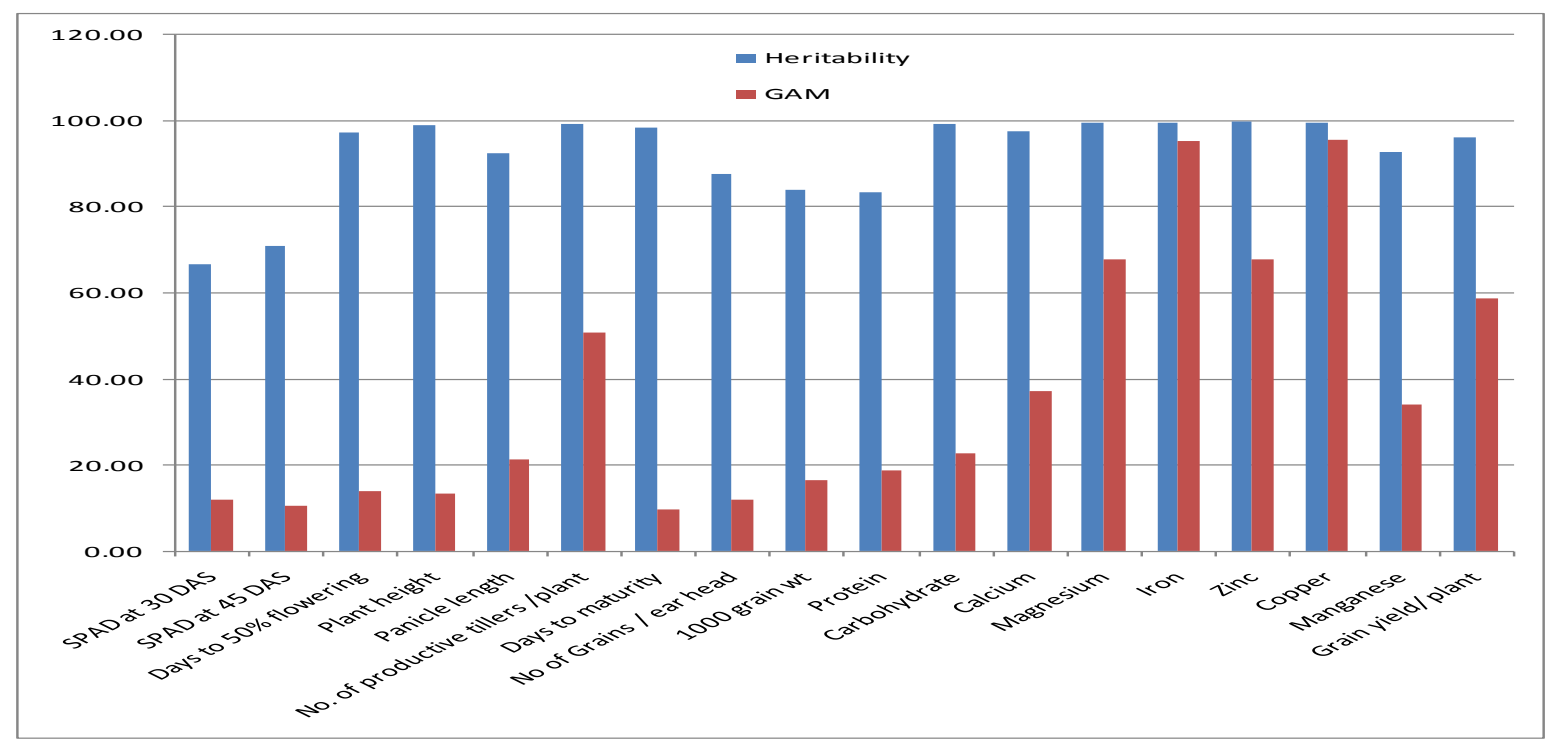


Table.1 ANOVA for 18 metric traits in 100 foxtail millet genetic resources studied

\begin{tabular}{|c|c|c|c|c|c|c|c|c|c|c|}
\hline \multirow[t]{2}{*}{ Source of variation } & d.f & $\begin{array}{c}\text { SCMR at } \\
\text { 30 DAS }\end{array}$ & $\begin{array}{l}\text { SCMR at } \\
45 \text { DAS }\end{array}$ & $\begin{array}{c}\text { Days to } \\
50 \% \\
\text { flowering }\end{array}$ & $\begin{array}{c}\text { Plant } \\
\text { height }\end{array}$ & $\begin{array}{l}\text { Panicle } \\
\text { length }\end{array}$ & $\begin{array}{l}\text { No. of } \\
\text { productive } \\
\text { tillers } \\
\text { /plant }\end{array}$ & $\begin{array}{l}\text { Days to } \\
\text { maturity }\end{array}$ & $\begin{array}{l}\text { No of grains / } \\
\text { ear head }\end{array}$ & $\begin{array}{c}1000 \text { grain } \\
\text { weight }\end{array}$ \\
\hline & & \multicolumn{9}{|c|}{ Mean sum of squares } \\
\hline Block & 7 & 6.964 & 4.797 & 0.21 & 1.403 & 0.479 & 0.016 & 0.139 & 2523.687 & 0.008 \\
\hline Entries & 99 & $19.742 * *$ & $19.519 * *$ & $15.182 * *$ & $161.298 * *$ & $5.727 * *$ & $1.231 * *$ & $32.266 * *$ & $18210.65 * *$ & $0.097 * *$ \\
\hline Checks & 3 & $56.620 * *$ & $85.518 * *$ & $75.115 * *$ & $1036.958 * *$ & $36.288 * *$ & $0.859 * *$ & $334.115 * *$ & $132431.7 * *$ & $0.229 * *$ \\
\hline Varieties & 95 & $18.556 * *$ & $17.366 * *$ & $12.252 * *$ & $121.583 * *$ & $4.787 * *$ & $1.165 * *$ & $19.052 * *$ & $14795.2 * *$ & $0.093 * *$ \\
\hline Checks vs. Varieties & 1 & 21.788 & $26.042 *$ & $113.753 * *$ & $1307.220 * *$ & $3.358 * *$ & $8.610 * *$ & $382.003 * *$ & 15.61 & 0.031 \\
\hline Error & 21 & 5.239 & 4.24 & 0.257 & 1.087 & 0.288 & 0.007 & 0.234 & 1484.97 & 0.012 \\
\hline \multirow[t]{2}{*}{$\begin{array}{l}\text { Sources of } \\
\text { variations }\end{array}$} & d.f & $\begin{array}{l}\text { Protein } \\
\text { (g/100g) }\end{array}$ & $\begin{array}{l}\text { Carbo- } \\
\text { hydrate } \\
\text { (g/100g) }\end{array}$ & $\begin{array}{l}\text { Calcium } \\
(\mathrm{mg} / \mathbf{1 0 0 g})\end{array}$ & $\begin{array}{c}\text { Magnesium } \\
\text { (mg/100g) }\end{array}$ & $\begin{array}{c}\text { Iron } \\
(\mathrm{mg} / 100 \mathrm{~g})\end{array}$ & $\begin{array}{c}\text { Zinc } \\
(\mathrm{mg} / \mathbf{1 0 0 g})\end{array}$ & $\begin{array}{c}\text { Copper } \\
(\mathrm{mg} / \mathbf{1 0 0 g})\end{array}$ & $\begin{array}{c}\text { Manganese } \\
\text { (mg/100g) }\end{array}$ & $\begin{array}{c}\text { Grain yield/ } \\
\text { plant (g) }\end{array}$ \\
\hline & & \multicolumn{9}{|c|}{ Mean sum of squares } \\
\hline Block & 7 & 0.588 & 0.546 & 0.122 & 0.16 & 0.104 & 0 & 0.001 & 0.027 & 0.747 \\
\hline Entries & 99 & $2.922 * *$ & $57.173 * *$ & $34.524 * *$ & $43.080 * *$ & $42.754 * *$ & $1.437 * *$ & $0.452 * *$ & $0.233 * *$ & $14.513 * *$ \\
\hline Checks & 3 & $5.320 * *$ & $4.716 * *$ & $336.718 * *$ & $311.224 * *$ & $250.694 * *$ & $0.726 * *$ & $1.195 * *$ & $0.784 * *$ & $23.160 * *$ \\
\hline Varieties & 95 & $2.875 * *$ & $59.345 * *$ & $24.419 * *$ & $31.566 * *$ & $31.096 * *$ & $1.463 * *$ & $0.433 * *$ & $0.215 * *$ & $14.170 * *$ \\
\hline Checks vs. Varieties & 1 & 0.202 & $8.184 * *$ & $87.879 * *$ & $332.457 * *$ & $526.524 * *$ & $1.184 * *$ & $0.062 * *$ & $0.214 * *$ & $21.188 * *$ \\
\hline Error & 21 & 0.388 & 0.33 & 0.446 & 0.111 & 0.093 & 0 & 0.002 & 0.012 & 0.43 \\
\hline
\end{tabular}

* Significant at $5 \%$ level

** Significant at $1 \%$ level 
Table.2 Mean, Variability, Heritability, Genetic advance as per cent of mean in 100 foxtail millet genetic resources

\begin{tabular}{|c|c|c|c|c|c|c|c|c|}
\hline \multirow[t]{2}{*}{ S.No. } & \multirow[t]{2}{*}{ Character } & \multirow[t]{2}{*}{ Mean } & \multicolumn{2}{|c|}{ Range } & \multicolumn{2}{|c|}{$\begin{array}{l}\text { Coefficient of } \\
\text { variation }\end{array}$} & \multirow{2}{*}{$\begin{array}{c}\text { Heritability } \\
\text { (broad sense) } \\
(\%)\end{array}$} & \multirow{2}{*}{$\begin{array}{c}\text { Genetic } \\
\text { advance as \% } \\
\text { of mean }\end{array}$} \\
\hline & & & Minimum & Maximum & $\begin{array}{l}\text { PCV } \\
(\%)\end{array}$ & $\begin{array}{l}\text { GCV } \\
(\%)\end{array}$ & & \\
\hline 1 & SCMR at 30 DAS & 46.34 & 34.7 & 55.2 & 8.56 & 7 & 66.8 & 11.78 \\
\hline 2 & SCMR at 45 DAS & 53.63 & 42.9 & 65.5 & 7.13 & 6.01 & 71.02 & 10.44 \\
\hline 3 & Days to $50 \%$ flowering & 44.93 & 32 & 54 & 6.93 & 6.84 & 97.36 & 13.91 \\
\hline 4 & Plant height $(\mathrm{cm})$ & 149.27 & 110.5 & 171.6 & 6.56 & 6.53 & 98.87 & 13.37 \\
\hline 5 & Panicle length $(\mathrm{cm})$ & 17.51 & 11 & 22.8 & 11.19 & 10.76 & 92.52 & 21.34 \\
\hline 6 & $\begin{array}{l}\text { No. of productive tillers } \\
\text { /plant }\end{array}$ & 3.84 & 1 & 6.4 & 24.85 & 24.75 & 99.2 & 50.77 \\
\hline 7 & Days to maturity & 81.99 & 60 & 92 & 4.73 & 4.7 & 98.46 & 9.6 \\
\hline 8 & No of Grains / ear head & 1677.68 & 1556.22 & 1820.12 & 6.54 & 6.12 & 87.65 & 11.8 \\
\hline 9 & 1000 grain wt $(\mathrm{g})$ & 2.91 & 1.57 & 3.53 & 9.47 & 8.68 & 84 & 16.4 \\
\hline 10 & Protein $(g / 100 g)$ & 14.1 & 10.5 & 18.38 & 10.88 & 9.94 & 83.52 & 18.73 \\
\hline 11 & Carbohydrate $(\mathrm{g} / 100 \mathrm{~g})$ & 61.87 & 50.05 & 76.42 & 11.09 & 11.05 & 99.3 & 22.68 \\
\hline 12 & Calcium (mg/100g) & 24.03 & 16 & 40 & 18.39 & 18.18 & 97.7 & 37.03 \\
\hline 13 & Magnesium (mg/100g) & 15.1 & 4.8 & 31.2 & 33.01 & 32.93 & 99.56 & 67.7 \\
\hline 14 & Iron $(\mathrm{mg} / 100 \mathrm{~g})$ & 10.88 & 4.42 & 32.5 & 46.42 & 46.33 & 99.62 & 95.26 \\
\hline 15 & Zinc (mg/100g) & 3.26 & 1.53 & 7.07 & 32.92 & 32.91 & 99.96 & 67.8 \\
\hline 16 & Copper $(\mathrm{mg} / 100 \mathrm{~g})$ & 1.26 & 0.86 & 2.76 & 46.57 & 46.47 & 99.54 & 95.5 \\
\hline 17 & Manganese (mg/100g) & 2.33 & 1.31 & 4.12 & 17.8 & 17.15 & 92.81 & 34.03 \\
\hline 18 & Grain yield/ plant (g) & 11.39 & 1.37 & 19.33 & 29.62 & 29.05 & 96.2 & 58.7 \\
\hline
\end{tabular}

$\mathrm{PCV}=$ Phenotypic coefficient of variation

$\mathrm{GCV}=$ Genotypic coefficient of variation 
High heritability estimates noted for all the metric characters, alone cannot design a suitable breeding method for selection of the better individuals. Hence, in order to fulfil the requirement, heritability estimates coupled with genetic advance are more reliable and useful genetic parameters in predicting the genetic gain under selection than heritability estimates alone and these will also give a good picture for having an idea of gene action involved (Kundu et al., 2008).

High heritability coupled with high genetic advance as per cent of mean (Table $2 \&$ Fig. 2) was reported for the traits copper, iron, zinc, magnesium, grain yield/ plant, number of productive tillers /plant,calcium ,manganese ,carbohydrate and panicle length indicating the predominance of additive gene action in governing these traits and direct selection would be effective for crop improvement programme. Similar works were reported by Nirubana et al. (2017) for grain yield / plant, number of productive tillers/plant.

In conclusion, wide spectrum of variation was observed for yield and its components in foxtail millet genetic resources. The analysis of genetic parameters revealed that the estimates of PCV were slightly higher than the corresponding GCV values for all the metric traits studied indicating that the characters were less influenced by the environment and thereby offering ample scope for improvement of the traits through simple phenotypic selection. The characters copper, iron, magnesium, zinc, grain yield/plant and number of productive tillers /plant registered higher PCV and GCV. High heritability coupled with high genetic advance as per cent of mean was observed for the traits copper, iron, zinc, magnesium, grain yield/ plant, number of productive tillers /plant,calcium ,manganese ,carbohydrate and panicle length indicating the predominance of additive gene action in governing these traits. It was also noticed that the traits copper, iron, magnesium, zinc, grain yield/plant and number of productive tillers /plant registered higher estimates of GCV, PCV, heritability and genetic advance as per cent of mean implying that these traits were predominantly under the control of additive gene action and their genetic improvement is achieved through simple selection strategies.

\section{Acknowledgement}

The authors thank Acharya N.G. Ranga Agricultural University for providing financial assistance and support in the conduct of experiment at RARS, Nandyal, A.P.

\section{References}

Annual report, AICRP on Small Millets. 2016- 17.

Burton, G.W and Devane, E.H. 1993. Estimating heritability in tall fescue (Festuca arundinaceae) from replicated clonal material. Agronomy journal. 45:478-481.

Johnson, H.W., Robinson., H. F and Comstock., R. E. 1955. Estimation of genetic and environmental variability in soybean. Agron. J., 47:314-318.

Lakshmana, D and Guggari, A.K. 2001. Karnataka journal of agricultural sciences. 14 (2): 311-314.

Lush, J.L. 1949. Heritability of quantitative characters in farm animals. Proceedings of 8th Congress of Genetics. Heriditas. 35:356-375.

Kavya, P., Sujatha, M., Pandravada, S.R. and Hymavathi, T.V. 2017. Variability studies in Foxtail millet (Setaria italica (L.) P. Beauv). International journal of current microbiology and applied sciences. 6(9): 955-960.

Kundu, A., Senapati, B.K., Bakshi, A and 
Mandal, G.S. 2008. Genetic variability of panicle characters in tall indica aman rice. Oryza. 45 (4): 320-323.

Mahanthesa, M., Sujatha, M., Meena, A.K and Pandravada, S.R. 2017. Studies on variability, heritability and genetic advance for quantitative characters in finger in finger millet (Eleusine coracana (L.) Gaertn) Germplasm. International journal of current microbiology and applied sciences. 6(6): 970-974.

Nirubana, V., Ganesamurthy, K., Ravikesavan, $\mathrm{R}$ and Chitdeshwari, $\mathrm{T}$. 2017. Genetic variability studies for yield and yield components in kodo millet (Paspalum scrobiculatum L.). 8 (2): 704-707.

Poehlman, J.M. 1987. Breeding field crops. $3^{\text {rd }}$ ed. AVI publishing company, Inc. West Port, CT. Pp. 187-213.

Reddy, C.V.C.M., Reddy, P.V.R.M., Munirathnam, P and Gowda, J. 2013. Indian journal of agricultural research.
47 (6): 549-552.

Reddy, C.V.C.M., Pullibai, P., Manjunath, J and Munirathnam, P. 2015. Genetic diversity and genotype by trait analysis for yield and yield attributing traits in foxtail millet (Setaria italica (L.) Beauv). International journal of agricultural innovations and research.3(6):1726-1730.

Shingane, S., Gomashe, S., Ganapathy, K.N and Patil, J.V. 2016. Genetic variability and association analysis for grain yield and nutritional quality in foxtail millet. International journal of bio-resource and stress management. 7(6): 1239-1243.

Upadhyaya, H.D., Pundir, R. P. S., Gowda, C. L. L V., Reddy, G and Singh,S..2009. Establishing a core collection of foxtail millet to enhance the utilization of germplasm of an underutilized crop. Plant Genetic Resources: Characterization and Utilization. 7(2): 177-184

\section{How to cite this article:}

Pavan Kumar, G.K., A.V.S. Durga Prasad, C.V. Chandra Mohan Reddy and Sreenivasulu, K.N. 2019. Genetic Variability Analysis for Yield and Nutritional Traits in Foxtail Millet [Setaria italica (L.) Beauv]. Int.J.Curr.Microbiol.App.Sci. 8(06): 2273-2279.

doi: https://doi.org/10.20546/ijcmas.2019.806.269 